\title{
Use of image analysis techniques to determine the embryo size of Senna multijuga (Rich.) seeds and its relation to germination and vigor ${ }^{1}$
}

\author{
José Luís de Marchi²*, Francisco Guilhien Gomes Junior²
}

\begin{abstract}
Semi-automatic evaluations of morphological attributes that are associated to seed germination performance such as the embryo size, have been of great interest when considering the study of image analysis techniques. The objective of this research was to evaluate the accuracy of the Tomato Analyzer software to quantify the variations on the embryo development degree of Senna multijuga seeds (Rich.) and its relationship with germination and tetrazolium tests. Seeds from four lots with different ripeness stages were X-rayed, evaluated according to the embryonic area and submitted to germination and tetrazolium tests. Results from the different parameters showed that the Tomato Analyzer ${ }^{\circledR}$ software is sensitive to assess the development degree of Senna multijuga seeds, when expressed by Pericarp Area parameter, but only the Area parameter was directly correlated with the physiological potential of the seed lots.
\end{abstract}

Index terms: silviculture, Tomato Analyser ${ }^{\circledR}$, quality, physiological potential.

\section{Utilização de técnicas de análise de imagens para determinação do tamanho do embrião em sementes de Senna multijuga (Rich.) e sua relação com a germinação e o vigor}

\begin{abstract}
RESUMO - A avaliação semiautomática de variações morfológicas associadas ao desempenho germinativo de sementes, como o tamanho do embrião, tem sido de grande interesse para os estudos das técnicas de análise de imagens. Sendo assim, visou-se avaliar a eficiência do software Tomato Analyzer ${ }^{\circledR}$ para quantificar o grau de desenvolvimento do embrião de sementes de Senna multijuga (Rich.) e sua relação com o teste de germinação e testes de tetrazólio. Para tanto, sementes provenientes de quatro lotes, obtidos de acordo com o estádio de maturação, foram radiografadas, submetidas à avaliação da área embrionária e avaliadas quanto à germinação e a viabilidade. Os resultados dos diferentes parâmetros obtidos evidenciaram que o software Tomato Analyzer ${ }^{\circledR}$ é sensível para avaliar o grau de desenvolvimento de sementes de Senna multijuga, quando se expressa o grau de desenvolvimento do embrião pelo parâmetro Área do Pericarpo, porém apenas o parâmetro Área apresentou relação direta com o potencial fisiológico dos lotes de sementes.
\end{abstract}

Termos para indexação: silvicultura, Tomato Analyser ${ }^{\circledR}$, qualidade, potencial fisiológico.

\section{Introduction}

Senna multijuga (Rich.), known as false sicklepod, belongs to the Mimosaceae family and occurs in almost all the country, mainly in the rainforest of the Atlantic slope (Carvalho, 2008) and in the semidecidual cloud forests of the states from Ceará to São Paulo. Due to the adaptation to various kinds of soils, it is proper to be used for revegetation programs in degraded areas and ciliary forests, as well as for urban forestry. Wood can be used for lightweight boxes, toys, fuel wood and coal (Lorenzi, 2002). It annually produces a great quantity of dormant seeds, dispersed by autochory, creating a seed bank (Carvalho, 2008); they were classified as orthodox (Carvalho and Nakagawa, 2000), also confirmed by Scalon et al. (2006). This species still presents silvicultural and ecological characteristics with potential for the implantation of forests by direct sowing. Thus, in order to rationally explore the potential of native species in the recovery of environments, it is extremely important to study seed quality, as well as the best way to produce seedlings.

The physiological quality of seeds is evaluated by fundamental parameters, such as viability and vigor. Vigor

\footnotetext{
${ }^{1}$ Submitted on 06/16/2016. Accepted for publication on 10/25/2016. 
tests have been used to identify differences in the physiological quality of lots presenting similar germination power and to complement the information provided by the germination test (Carvalho and Nakagawa, 1988). In order to determine seed vigor, the first germination count test, the seedling emergence test, the electrical conductivity test and the accelerated aging test may be efficiently used. However, the tetrazolium test is a feasible alternative, because it is quick França-Neto (1999). In this sense, studies about vigor are important to obtain information about the period when seeds may remain feasible and about the deterioration and death of seeds.

The development of methods to quickly evaluate the physiological quality of seeds may help deciding about the use or discard of lots meant for the conservation and/ or production of seedlings. With the use of image analysis techniques, objective information may be obtained, in a relatively short period, with less human interference and, in many cases, without destroying seeds. Moreover, recorded images can be catalogued, stored and used to define nonsubjective and standardized evaluation criteria.

One of the morphological variations probably associated to the seed performance is the size of the embryo, that is, its development degree in relation to the available space in the seed internal cavity, estimated in a proportion expressed in percentage. This characteristic has been evaluated through image analysis in x-rayed seeds (Machado and Cicero, 2003; Pupim et al., 2008; Otoni et al., 2005), trying to associate the results to germination and vigor. However, aiming at a higher analysis precision, it is important to use specific softwares. The Tomato Analyzer ${ }^{\circledR}$ (TA) software allows substituting evaluations of morphological attributes through manual or subjective estimation measures (Brewer et al., 2006; Brewer et al., 2007; Brewer et al., 2008). The system makes quantitative evaluations in an objective and semi-automatic way, accelerating the phenotypic analysis and obtaining highly consistent and repeatable information. Thus, the goal of this study was to evaluate the efficacy of using image analysis techniques, including the Tomato Analyzer ${ }^{\circledR}$ (TA) software, in order to determine the internal morphology and its relation with the vigor of Senna multijuga seeds.

\section{Materials and Methods}

The research was developed in the Seed Testing and Image Analysis Laboratory of the Plant Production Department (PPD) of the Escola Superior de Agricultura "Luiz de Queiroz", Universidade de São Paulo, in Piracicaba, São Paulo state, with seeds coming from the Instituto de Pesquisas e Estudos Florestais (IPEF), in Piracicaba, São Paulo state, Brazil.
Fruits were harvested with the help of trimmers and plastic canvas from fifteen mother plants, in different ripeness stages, when they presented green to green-yellow-brownish colors; pods were still closed and they were placed in a shaded environment, for drying and later seed extraction.

Seeds were separated by color using Munsell color paper (1994), creating four Lots: L1 - initial population (control sample); L2 - medium green (2.5GY 5/8, equal or darker tone in relation to the standard color $2.5 \mathrm{GY} 6 / 6$ ); L3 - light olive green $(2.5 \mathrm{GY} 2 / 4$, darker tone in relation to the standard color 2.5GY 6/6); L4 - mix of L1, L2 and L3 treatment. It was considered that Lot 1 was composed by ripe seeds. On the other hand, Lots 2, 3 and 4 presented different ripeness stages.

After obtaining the lots, seeds were submitted to a treatment to overcome dormancy, constituted by acid scarification, where they were immersed in sulphuric acid $\left(\mathrm{H}_{2} \mathrm{SO}_{4}\right)$ at $90 \%$, for 20 minutes.

After treatment, seeds were evaluated by the following tests:

Determination of seed moisture content: four replications of twenty seeds were used for each lot, through oven method at $105 \pm 3{ }^{\circ} \mathrm{C}$, for 24 hours, according to the prescriptions from the Rules for Seed Testing (Brasil, 2009); results were expressed in percentage (wet basis).

Germination test: conducted with four replications of 50 seeds for each lot, which were placed in paper towel, dampened with distilled water, equivalent to 2.5 times the mass of dry paper. Seeds were placed in a germinator adjusted at the temperature of $25^{\circ} \mathrm{C}$, with photoperiod of 12 hours (Brasil, 2009).

Tetrazolium test: seeds were scarified with the help of sandpaper (80) on the opposite side of the embryo, and immersed for 14 hours in distilled water, at $25{ }^{\circ} \mathrm{C}$. After hydration, the tegument and endosperm were removed with the help of a blade and the embryos were immersed in tetrazolium solutions at $0.1 \%$ concentration, remaining incubated for 5 hours in oven at $35^{\circ} \mathrm{C}$, in the dark. After incubation, embryos were washed with distilled water and longitudinally sectioned with a blade. Evaluations were performed with the help of a stereo microscope; a seed classification standard was elaborated, classifying them as viable (fully colored embryo), intermediate (colored areas represent the minimum area of the embryo necessary for normal germination) and unviable (non-colored embryo). The test was performed with four replications of 25 seeds for each lot.

$X$-ray analysis: in order to obtain $\mathrm{x}$-ray images of the seeds, the Faxitron X-ray digital equipment was used, MX20 DC-12 model, connected to a Core 2 Due computer (3.16 Ghz, 2 GB of RAM memory, 160 GB Hard Disk) and a 17' MultiSync LCD1990SX monitor. Two hundred seeds 
were x-rayed (4 replications of 50 seeds) for each lot and X-rays were obtained with seeds placed at $28.6 \mathrm{~cm}$ from the emission source. The radiation intensity and exposure time of seeds were automatically determined by the x-ray device. In order to properly position seeds during the exposure to $\mathrm{x}$-rays, a transparent double-face tape was used, bonded to a rear projection transparent film $(29.7 \times 21.0 \times 0.1 \mathrm{~cm})$. After $\mathrm{x}$-rays, seeds were placed in individualized cells on a plastic tray (100 cells/tray) for later germination. X-ray images were stored in the computer hard disk for future analysis of seed physical parameters by TA software.

Software Tomato Analyzer ${ }^{\circledR}$ : after obtaining x-rays, seeds from the respective lots were individually submitted to evaluation by the software. The methodology described by Marcos-Filho et al. (2010) was adapted, using it to determine the parameter of the Pericarp Area, since in this research other parameters generated by the software were considered.

Germination after x-rays: seeds coming from the x-ray test, previously numbered, were distributed over two paper towel sheets, on the upper third of the substrate, covered with one more sheet and rolled. Paper sheets were moistened with a quantity of water equivalent to 2.5 times their mass. For each lot, eight replications of twenty-five seeds were used. Rolls were kept at $25^{\circ} \mathrm{C}$ in BOD chamber with 8 light hours and 16 dark hours. Evaluations were performed on day 11, 16 and 28 after test establishment and germination data were expressed in percentage of normal seedlings (Brasil, 2009).

After analyzing and evaluating each seed, the software automatically generated numeric values, referring to morphologic parameters, that is: Perimeter, Area and Pericarp Area. It is important to highlight that the adopted procedure to interpret the Pericarp Area parameter was the one detailed by Marcos-Filho et al. (2010). Considering the different parameters evaluated by the software, images of the $\mathrm{x}$-rayed seeds were submitted to the statistic analysis, with the goal of establishing different classes and relations with the results of other vigor tests, usually conducted for the species seeds, according to the methodology proposed by Silva and Cícero (2014).

The experimental design was completely randomized with four treatments and replications, with averages compared by Tukey's test $(\mathrm{p} \leq 0.05)$.

\section{Results and Discussion}

Results of water content (U\%), germination ( $\mathrm{G} \%$ ), tetrazolium $(\mathrm{Tz} \%)$ and germination after the $\mathrm{x}$-rays tests for the four lots of $S$. multijuga seeds can be found in Table 1 . Seeds presented water content between 10.4 and $11.2 \%$ and great variations were not found among seed lots; this fact must be considered in the evaluation of the physiological potential, since variations above $2 \%$ among samples may interfere with the results (Marcos-Filho and Kikuti, 2006; Tekrony, 2003).

Still, compared to the physiological classification of seeds presented by Amorim et al. (2008), this species shows a similar behavior to the one of orthodox species, since even with a low water content, they remain feasible after five months of storage. This behavior is also observed in species forming a seed bank as an establishment strategy, as well as abundant production and high-longevity seeds (Ferreira et al., 2004).

It was possible to observe that evaluations on germination, tetrazolium and $\mathrm{x}$-rayed seed germination identically classified all four lots as for physiological quality (Table 1); lot 1 had high physiological quality and lot 4 had low physiological quality. Moreover, the compliance of the criterion used to obtained the different lots was verified, according to which some Munsell color paper was used to separate seeds in different ripeness stage, allowing the obtainment of the four lots at issue. Similarly, Lopes et al. (2005), in their studies with Tibouchina granulosa seeds, observed that the size of fruits and color of seeds are indicators of the physiological ripeness stage. Moreover, Martins and Silva (1997) reported that the moisture degree and dry matter mass were the parameters that best characterized the physiological ripeness in Dalbergia nigra (Vell.) Fr. All.ex Benth. seeds.

According to the classification proposed by França-Neto et al. (1998), results obtained by tetrazolium test (Table 1) allowed verify that seed lot 1 had a very high vigor lot, whereas lot 2 had high vigor and lots 3 and 4 had medium vigor. It is important to highlight that the tetrazolium test presented the same lot classification as the germination test. This demonstrated that

Table 1. Evaluation of the initial viability of four Senna multijuga seed lots, by the results obtained in tests on seed moisture content $(\mathrm{M})$, germination $(\mathrm{G})$, tetrazolium (TZ) and germination after x-ray analysis (G x-ray). NS - normal seedlings; AS abnormal seedlings and DS - dead seeds.

\begin{tabular}{ccccccr}
\hline Lot & M & G & TZ & \multicolumn{3}{c}{ G (x-rays) } \\
\hline & & & & NS & AS & DS \\
& & & & & & \\
& & $(\%)$ & & & $(\%)$ & \\
\hline 1 & $11.22 \mathrm{~A}^{*}$ & $85 \mathrm{~A}$ & $86 \mathrm{~A}$ & $87 \mathrm{~A}$ & $4 \mathrm{~A}$ & $9 \mathrm{~A}$ \\
2 & $11.10 \mathrm{~B}$ & $76 \mathrm{~B}$ & $73 \mathrm{~B}$ & $77 \mathrm{~B}$ & $9 \mathrm{~B}$ & $14 \mathrm{~B}$ \\
3 & $10.65 \mathrm{C}$ & $73 \mathrm{C}$ & $63 \mathrm{C}$ & $73 \mathrm{C}$ & $11 \mathrm{~B}$ & $16 \mathrm{~B}$ \\
4 & $10.43 \mathrm{D}$ & $64 \mathrm{D}$ & $52 \mathrm{D}$ & $63 \mathrm{D}$ & $14 \mathrm{C}$ & $13 \mathrm{~B}$ \\
\hline $\mathrm{CV}(\%)$ & 2.00 & 16.4 & 20.1 & 18.6 & 7.1 & 5.2 \\
\hline
\end{tabular}

* Means followed by the same letters, in each column, do not differ among themselves by Tukey's test at $5 \%$ significance. 
the tetrazolium test may be used to efficiently evaluate the physiological quality of false sicklepod seeds.

These results support the ones obtained by Piveta et al. (2010) and Ferreira et al. (2004), who report that the tetrazolium test $\left(0.075 \%\right.$ concentration and $\left.30{ }^{\circ} \mathrm{C}\right)$ with incubation for 5 hours, was effective in evaluating the vigor and viability of $S$. multijuga seeds, in laboratory or coming from the soil seed bank.

By examining the images of $S$. multijuga seeds and by the analysis of germination data obtained after the x-ray test (Table 1), it is possible to observe that most seeds presenting a fully filled embryonic cavity, with well formed embryonic axis and endosperm (Figure 1A) or embryonic cavity with more than 50\% filling, with well formed embryonic axis and endosperm originated normal seedlings, regardless of the lot (Figure 1A). It is possible that the wider the seed internal area occupied by the embryo and endosperm, the higher the germination potential, since with a more developed embryo, a lower energy expenditure will be necessary for its development, as well as the higher endosperm quantity constitutes more available energy for the process. According to Marchi et al. (2011), some seeds presenting normal characteristics at the x-ray test, may present germination problems, possibly because of invisible infections with physiologically damaged or dead microorganisms and seeds, due to deterioration. Moreover, according to Socolowski and Cícero (2008), seeds that emitted the primary root and did not create normal seedlings could be at the initial stage of viability loss. However, it is important to highlight that various aspects shall be considered in the study of seed morphology. As well as the internal cavity occupied by the embryo and endosperm, the presence of mechanical damages, stains indicating tissue deterioration or seed malformations are characters that may influence germination.
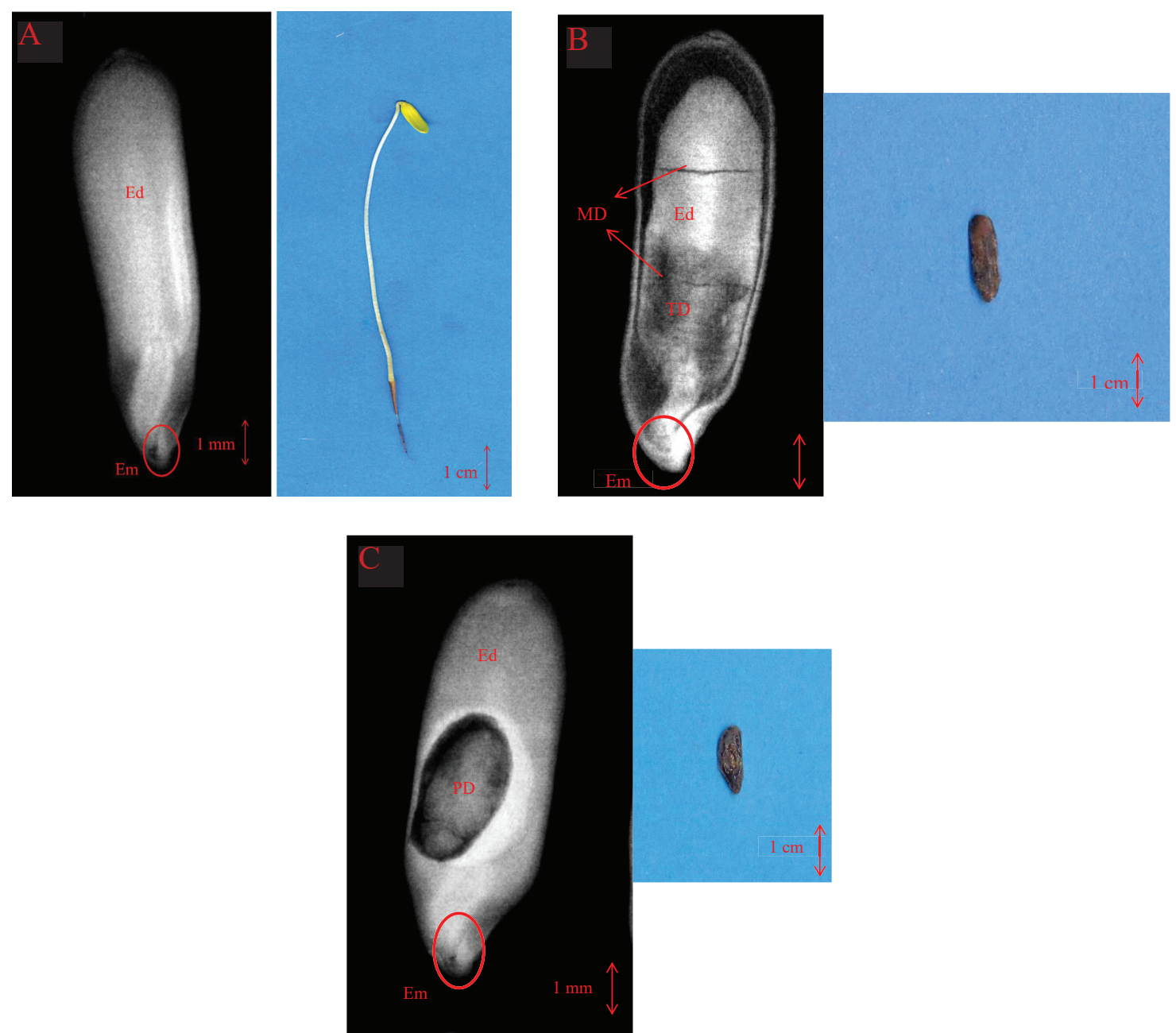

Figure 1. Seeds without damages from any species in the embryo (Em) and endosperm (Ed), originating normal seedlings (A); seeds with damages by tissue deterioration (TD) and mechanical damages (MD) originating dead seeds (B) and seeds with damages from insect predation (PD) originating dead seeds (C).

Journal of Seed Science, v.39, n.1, p.013-019, 2017 
Generally speaking, results from the x-ray test classified lot 1 as the one with best quality and lot 4 as the one with worst quality. Results of malformed seed percentage, predated seeds, seeds with deteriorated tissues and seeds with mechanical damages are presented in Table 2. By data analysis, most seeds originated abnormal seedlings or dead seeds. However, these results must be compared with the ones observed in Table 1, that is, it is possible to observe that lot 4, with the highest percentage of malformed seeds and deteriorated tissues, presented lower percentage of normal seedlings and higher percentage of abnormal seedlings, in opposition to lot 1 (Table 1). However, lot 1, with the highest percentage of predated seeds, presented higher percentage of normal seedlings and lower percentage of abnormal seedlings (Table 1). Therefore, there is dependency of type and location of the damage on seeds and development of normal seedlings, abnormal seedlings or dead seeds. Similarly observed Marchi et al. (2011), who used the x-ray test as the procedure to evaluate the internal morphology and associate it with the physiological quality of peanut seeds. According to Socolowski and Cícero (2008), seed mass is an indicator of their physiological quality and x-ray images are important to observe the physical quality of seeds; this was similarly observed by Masetto et al. (2007), analyzing images of Eugenia pleurantha. Moreover, similarly to what was observed by Oliveira et al. (2004) in yellow ipe (Tabebuia serratifolia Vahl Nich.) and pink ipe (Tabebuia impetiginosa (Martius ex A. P. de Candolle) Standley) seeds, the x-ray test was effective in evaluating the internal morphology of pink trumpet tree (Tabebuia heptaphylla) seeds, and the internal damages detected in the x-rays affected germination, reducing the lot quality.

Parameters obtained by seed image analysis, using the Tomato Analyzer ${ }^{\circledR}$ software, can be found in Table 3. By the analysis of data, it is possible to observe that of all parameters evaluated by the software, the only one presenting significant differences among the lots the one evaluating seed area. Therefore, results are opposed to what was obtained by Gomes-Junior et al. (2013), who evaluated the effectiveness of the Tomato Analyzer ${ }^{\mathbb{R}}$ software in identifying variations in the development degree of the embryo and their possible relation with the physiological potential in cucumber seeds. The authors concluded that the semi-automated analysis, performed with the help of the Tomato Analyzer ${ }^{\circledR}$ software, allowed identifying close variations in the development degree of the embryos from different lots of cucumber seeds, observing that seeds whose embryonic area occupied less than $78.1 \%$ of the internal cavity were more likely to originate less developed seedlings. It is also worth mentioning that researches conducted by Machado and Cicero (2003), Pupim et al. (2008) and Otoni and McDonald (2005), which tried to associate the results of embryo development degree in relation to the available space in the seed internal cavity, estimated in a proportion expressed in percentage evaluated through image analysis techniques, to germination and vigor.

Studying S. multijuga seed morphology, Amorim et al. (2008) highlighted that the species present important characteristics that may help not only its identification, but that also affect the analysis of physiological quality, such as fruit characteristics, mainly dehiscence, shape, color and pericarp texture, common in the subfamily and seeds with the presence of closed pleurogram, areola and endosperm.

These characteristics may have caused the differences verified in the seed area (parameter A; Table 3), detected by the Tomato Analyzer ${ }^{\circledR}$ software, without significantly affect the relation between the existing free space area between embryo and tegument, influencing the physiological quality of different seed lots.

Table 2. Percentage (\%) of Senna multijuga seeds from different damage classes characterized by the performance of $\mathrm{X}$-ray tests. Seeds without damages (SD); malformed seeds (MS); predated seeds (PS); deteriorated seeds (DS); seeds with mechanical damages (MD).

\begin{tabular}{cllclc}
\hline Lot & SD & MS & PS & DS & MD \\
\hline & & \multicolumn{5}{c}{$(\%)$} \\
\hline 1 & $92 \mathrm{~A}^{*}$ & $1 \mathrm{~A}$ & $1 \mathrm{~A}$ & $4 \mathrm{~A}$ & $1 \mathrm{~A}$ \\
2 & $86 \mathrm{~B}$ & $3 \mathrm{AB}$ & $3 \mathrm{~B}$ & $7 \mathrm{~B}$ & $1 \mathrm{~A}$ \\
3 & $87 \mathrm{~B}$ & $4 \mathrm{~B}$ & $3 \mathrm{~B}$ & $5 \mathrm{AB}$ & $1 \mathrm{~A}$ \\
4 & $79 \mathrm{C}$ & $8 \mathrm{C}$ & $3 \mathrm{~B}$ & $8 \mathrm{~B}$ & $2 \mathrm{~A}$ \\
\hline $\mathrm{CV}(\%)$ & 9.6 & 10.1 & 1.1 & 4 & 1.2 \\
\hline
\end{tabular}

*Means followed by the same letters, in each column, do not differ among themselves by Tukey's test at 5\% significance

Table 3. Mean values of perimeter (P), area (A), pericarp area (PA), generated from the analysis performed by the Tomato Analyser ${ }^{\circledR}$ software, of $\mathrm{x}$-ray images obtained in the X-ray test of four Senna multijuga seed lots.

\begin{tabular}{cccc}
\hline \multirow{2}{*}{ Lot } & $\mathrm{P}$ & $\mathrm{A}$ & $\mathrm{PA}$ \\
\cline { 2 - 4 } & $(\mathrm{mm})$ & $\left(\mathrm{mm}^{2}\right)$ & $\left(\mathrm{mm}^{2}\right)$ \\
\hline 1 & $22.94491 \mathrm{~A}^{*}$ & $81.654415 \mathrm{~A}$ & $0.01203 \mathrm{~A}$ \\
2 & $22.6462 \mathrm{~A}$ & $81.451482 \mathrm{~A}$ & $0.01197 \mathrm{~A}$ \\
3 & $22.25488 \mathrm{~A}$ & $79.669007 \mathrm{AB}$ & $0.01197 \mathrm{~A}$ \\
4 & $22.04137 \mathrm{~A}$ & $76.915258 \mathrm{~B}$ & $0.01197 \mathrm{~A}$ \\
\hline CV $(\%)$ & 2.36 & 2.37 & 0.36 \\
\hline
\end{tabular}

*Means followed by the same letters, in each column for each period, did not differ among themselves by Tukey's test at $5 \%$ significance. 
Thus, the results of this work demonstrated that for $S$. multijuga seeds, the measure of the seed Area parameter (A) expressed in a more evident way the differences in the physiological potential of lots compared to the Pericarp Area (PA) parameter, which evaluates the relation between the existing free space area between the embryo and the tegument.

\section{Conclusions}

The $\mathrm{x}$-ray image test is effective to evaluate the internal morphology of Senna multijuga seeds and their relation with vigor.

The Tomato Analyzer ${ }^{\circledR}$ software is sensitive to evaluate the development degree of Senna multijuga seeds.

\section{References}

AMORIM, I.L.; DAVIDE, A.C.; FERREIRA, R.A.; CHAVES, M.M.F. Morfologia de frutos, sementes, plântulas e mudas de Senna multijuga var. lindleyana (Gardner) H. S. Irwin \& Barneby - Leguminosae Caesalpinioideae. Revista Brasileira de Botânica, v.31, n.3, p.507-516, 2008. http://www.scielo.br/pdf/rbb/v31n3/ a14v31n3.pdf

BRASIL. Ministério da Agricultura, Pecuária e Abastecimento. Regras para análise de sementes. Ministério da Agricultura, Pecuária e Abastecimento. Secretaria de Defesa Agropecuária. Brasília: MAPA/ACS, 2009. 395p. http://www.agricultura.gov.br/arq editor/ file/Laborat $\%$ C3\%B3rio/Sementes/Regras $\% 20$ para\%20Analise $\% 20$ de $\% 20$ Sementes.pdf

BREWER, M.T.; LANG, L.; FUJIMURA, K.; DUJMOVIC, N.; GRAY, M.; VAN DER KNAAP, E. Development of a controlled vocabulary and software application to analyze fruit shape variation in tomato and other plant species. Plant Physiology, v.141, n.1, p.1525, 2006. http://dx.doi.org/10.1104/pp.106.077867

BREWER, M.T.; MOYSEENKO, J.B.; MUNFORTE, A.J.; VAN DER KNAAP, E. Morphological variation in tomato: a comprehensive study of quantitative trait loci controlling fruit shape and development. Journal of Experimental Botany, v.58, n.6, p.1339-1349, 2007. http://jxb.oxfordjournals.org/content/58/6/1339

BREWER, M.T.; RODRIGUEZ, G.; GONZALO, M.J.; LANG, L.; SULLIVAN, D.; DUJMOVIC, N.; FUJIMURA, K.; GRAY, S.; VAN DER KNAAP, E. Tomato Analyzer (TA) user manual version 2.2.00. 18 p. 2008. http://www.oardc.ohio-state.edu/vander knap. Accessed on: March. 24 $4^{\text {th }}, 2016$.

CARVALHO, N.M.; NAKAGAWA, J. Sementes: ciência, tecnologia e produção. Campinas: Fundação Cargill, 1988. 424p.

CARVALHO, N.M.; NAKAGAWA, J. Sementes: ciência, tecnologia e produção. 4.ed. Jaboticabal: FUNEP, 2000. 588p.

CARVALHO, P.E.R. Espécies Arbóreas Brasileiras. Brasília, DF: Embrapa Informação Tecnológica; Colombo: Embrapa Florestas, 2008, v.3, 593p.
FERREIRA, R.A.; DAVIDE, A.C.; MOTTA, M.S. Vigor e viabilidade de sementes de Senna multijuga (Rich.) Irwin et Barn. e Senna macranthera (Collad.) Irwin et Barn., num banco de sementes em solo de viveiro. Revista Brasileira de Sementes, v.26, n.1, p.2431, 2004. http://www.scielo.br/pdf/rbs/v26n1/a04v26n1.pdf

FRANÇA-NETO, J.B.; KRZYZANOWSKI, F.C.; COSTA, N.P. O teste de tetrazólio em sementes de soja. Londrina: EMBRAPACNPSo, 1998. 72p. (EMBRAPA-CNPSo. Documentos, 116).

FRANÇA-NETO, J.B. Teste de tetrazólio para determinação do vigor de sementes. In: KRYZANOWSKI, F.C.; VIEIRA, R.D.; FRANCCA-NETO, J.B. Vigor de sementes: conceitos e testes. Londrina. ABRATES, 1999. p.8.1-8.28

GOMES-JUNIOR, F.G.; CHIQUITO, A.A.; MARCOS-FILHO, J. Semi-automated assessment of the embryonic area of cucumber seeds and its relationship to germination and seedling length Journal of Seed Science, v.35, n.2, p.183-189, 2013. http://dx.doi. org/10.1590/S2317-15372013000200007

LOPES, J.C.; DIAS, P.C.; PEREIRA, M.D. Maturação fisiológica de sementes de quaresmeira. Pesquisa Agropecuária Brasileira, v.40, n.8, p.811-816, 2005. http://www.scielo.br/pdf/pab/v40n8/ a12v40n8.pdf

LORENZI, H. Árvores Brasileiras: manual de identificação e cultivo de plantas arbóreas do Brasil. 2.ed. São Paulo: Nova Odessa, 2002. v.2. 384p.

MACHADO, C.F.; CÍCERO, S.M. Aroeira-branca (Lithraea molleoides (Vell.) Engl. - Anacardiaceae) seed quality evaluation by the X-ray test. Scientia Agricola, v.60, n.2, p.393-397, 2003. http:// www.scielo.br/pdf/sa/v60n2/15344.pdf

MARCHI, J.L.; CICERO, S.M.; GOMES JUNIOR, F.G. Utilização da análise computadorizada de plântulas na avaliação do potencial fisiológico de sementes de amendoim tratadas com fungicida e inseticida. Revista Brasileira de Sementes, v.33, n.4, p.652-662, 2011. http://www.scielo.br/pdf/rbs/v33n4/07.pdf

MARCOS-FILHO, J.; KIKUTI, A.L.P. Vigor de sementes de rabanete e desempenho de plantas em campo. Revista Brasileira de Sementes, v.28, n.3, p.44-51, 2006. www.scielo.br/pdf/rbs/v28n3/07.pdf

MARCOS-FILHO, J.; GOMES JUNIOR, F.G.; BENNETT, M.A.; WELLS, A.A.; STIEVE, S. Using tomato analyzer software to determine embryo size in x-rayed seeds. Revista Brasileira de Sementes, v.32, n.2, p.146-153, 2010. http://www.scielo.br/pdf/rbs/ v32n $2 / v 32 n 2 a 18 . p d f$

MARTINS, S.V.; SILVA, D.D. Maturação e época de colheita de sementes de Dalbergia nigra (Vell.) Fr. All. ex Benth. Revista Brasileira de Sementes, v.19, n.1, p.96-99, 1997. http://www.abrates. org.br/revista/artigos/1997/v19n1/artigo18.pdf

MASETTO, T.E.; DAVIDE, A.C.; SILVA, E.A.A.; FARIA, J.M.R. Avaliação da qualidade de sementes de Eugenia pleurantha (Myrtaceae) pelo teste de raios X. Revista Brasileira de Sementes, v.29, n.3, p.170-174, 2007. http://www.scielo.br/scielo. php?script $=$ sci_arttext\&pid $=$ S0101-31222007000300020 
MUNSELL COLOR COMPANY. Macbeth, Division of Kolmorgen Instruments Corporation. Munsel. Soil Color Charts, New Windsor, 1994. 10p.

OLIVEIRA, L.M .; CARVALHO, M.L.M .; GUIMARÃES, R.M ;; MASETTO, T.E. Avaliação da qualidade de sementes de Tabebuia serratifolia Vahl Nich. e T. impetiginosa (Martius ex A. P. de Candolle) Standley - (Bignoniaceae) pelo teste de raios X. Revista Brasileira de Sementes, v.26, n.2, p.138-143, 2004. http://www. scielo.br/pdf/rbs/v26n2/24500.pdf

OTONI, R.R.; McDONALD, M.B. Moisture and temperature effects on maize and soybean seedlings using the seed vigor imaging system. Seed Technology, v.27, n.2, p.243-247, 2005. http://www. seedtechnology.net/journal/st27no2.pdf

PIVETA, G.; MENEZES, V.O.; PEDROSO, D.C.; MUNIZ, M.F.B.; BLUME, E.; WIELEWICKI, A.P. Superação de dormência na qualidade de sementes e mudas: influência na produção de Senna multijuga (L. C. Rich.) Irwin \& Barneby. Acta Amazônica, v.40, n.2, p.281-288, 2010. www.scielo.br/pdf/aa/v40n2/v40n2a06.pdf

PUPIM, T.L.; NOVEMBRE, A.D.L.C.;CARVALHO, M.L.M.; CICERO, S.M. Adequação do teste de raios-X para avaliação da qualidade de sementes de embaúba (Cecropia pachystachya Trec). Revista Brasileira de Sementes, v.30, n.2, p.28-32, 2008. http://www.scielo.br/pdf/rbs/v30n2/a04v30n2.pdf
SCALON, S.P.Q.; MUSSURY, R.M.; SCALON FILHO, H.; FRANCELINO, C.S.F.F.; FLORENCIO, D.K.A. Armazenamento e tratamentos pré-germinativos em sementes de jacarandá (Jacaranda cuspidifolia Mart.) Revista Árvore, v.30, n.2, p.179-185, 2006. http:// www.scielo.br/pdf/rarv/v30n2/a04v30n2

SILVA, V.N.; CICERO S.M. Análise de imagens de plântulas para avaliação do potencial fisiológico de sementes de berinjela. Horticultura Brasileira, v.32, n.32, p.145-151, 2014. http://www. scielo.br/pdf/hb/v32n2/0102-0536-hb-32-02-00145.pdf

SOCOLOWSKI, F.; CÍCERO, S.M. Caracterização morfológica de embriões por imagens de raios $\mathrm{X}$ e relação com a massa e a qualidade fisiológica de sementes de Tecoma stans L. Juss ex Kunth (Bignoniaceae). Revista Brasileira de Sementes, v.30, n.2, p.200208, 2008. http://www.scielo.br/pdf/rbs/v30n2/a25v30n2.pdf

TEKRONY, D.M. Precision is an essential component in seed vigour testing. Seed Science and Technology, v.31, n.2, p.435-447, 2003. https://doi.org/10.15258/sst.2003.31.2.20 